\title{
Ayurvedic Management of Primary Open Angle Glaucoma
}

\author{
Archana V K ${ }^{1}$, Vaghela $D^{2}$ \\ ${ }^{1} \mathrm{PhD}$ Scholar, ${ }^{2}$ Associate Professor, Institute for Post Graduate Teaching and research in Ayurveda, Gujarat \\ Ayurved University, Jamnagar
}

\begin{abstract}
Primary open angle glaucoma (POAG) is a chronic, progressive optic neuropathy causing irreversible vision loss. Currently available conventional options have certain limitations; considering which options from alternative resources are being searched. Ayurvedic treatment principles which are targeted towards the basic pathophysiology can play a significant role in the integrated management of this disease. In this case study, Ayurvedic treatment was done along with conventional treatment. A male patient aged 58 years visited Shalakaya - Netra OPD complaining defective vision for both distance and near since six months. He was a diagnosed case of POAG since 5 years and was on Latanoprost eye drops once daily. He was given Deepana, pachana, anulomana, Shiro virechana and six sittings of Tarpana with Shigru Arka. He was also taking Rasayana yoga ( herbomineral formulation with rejuvenating properties) for three months. There was improvement in visual acuity in both eyes along with significant reduction of intraocular pressure. Visual field analysis showed improvement in retinal sensitivity. Blood parameters showed no significant changes in hematological and biochemical parameters except for reduction in Triglyceride value from 205 $\mathrm{mg} / \mathrm{dl}$ to $153 \mathrm{mg} / \mathrm{dl}$. Thus, it can be concluded that Ayurvedic approach is helpful in giving a complimentary treatment protocol for Primary open angle glaucoma.
\end{abstract}

Key words: Ayurveda, Nasya, Primary open angle glaucoma, Rasayana, Tarpana.

\section{INTRODUCTION}

Primary open angle glaucoma (POAG) can be considered as a chronic progressive optic neuropathy that is accompanied by a characteristic cupping and atrophy of the optic disc, visual field loss and open angles and no obvious causative ocular or systemic conditions ${ }^{1}$. It is the second leading cause of blindness worldwide ${ }^{2}$. The characteristic optic nerve cupping results from slowly progressive loss of retinal ganglion cells and their neurons which is irreversible. This disease has a hereditary component and becomes more prevalent with age. Since the disease is slowly progressive and asymptomatic until late in its course, affected individuals can develop severe damage before seeking medical care.

Since IOP is the only modifiable risk factor to prevent the progress of the disease, most of the treatment modalities are directed towards its reduction. But the neurodegeneration continues even after lowering IOP and this has lead to the exploration of neuroprotective treatment strategies. Ayurveda has potent treatment strategies in site specific neuroprotection. The progressive visual function loss can be successfully tackled and controlled by using Chakshushya Rasayanas which act upon the pathogenesis of the disease and strengthens the occular tissues. An ideal anti glaucoma treatment should sustain sufficient reduction in intraocular pressure for longer duration; preserve visual fields, devoid of side effects and at the same time compatible with currently available treatment strategies ${ }^{3}$. In this case of POAG, Ayurvedic treatment was done along with conventional treatment.

\section{CASE REPORT}

A 58 years old moderate built, male working as a tailor reported to the OPD on 16-06-2016 complaining of gradual painless diminution of distant as well as near vision for the last two years and was severe since 2 months. He also had side vision difficulty more pronounced in his right eye, delayed dark adaptation and frequent changes in near vision glasses since 2 years. He was a known case of POAG diagnosed since 5 years, using topical Latanoprost eyedrops. He was also diabetic and hypertensive and was on oral 
Archana V K ${ }^{1}$, International Journal of Ayurvedic\& Herbal Medicine 7(6) Nov.-Dec. 2017 (3024-3029)

hypoglycemic and anti-hypertensive medicines since last 5 years. On his visit to the OPD, he had good glycemic control. He was a chronic smoker, had a habit of smoking for the past few years (about 10 cigarettes per day), which he stopped about a year before the day of assessment. There was family history of POAG (Mother with end stage optic atrophy). He came to OPD enquiring Ayurvedic solutions for his condition. Ayurvedic treatment was started on 22.06.2016 after detailed assessment of his visual functions and optic nerve head characteristics.

\section{Clinical findings}

He was afebrile. Pulse was 75/minute. Respiratory Rate was 18/minute and Blood Pressure was 130/90 $\mathrm{mmHg}$. Systemic examination of respiratory, circulatory, digestive systems etc were within normal limits.

\section{Visual examination}

Distant visual acuity by Snellen's chart was 6/18 OD and 6/12p O S. Best corrected visual acuity in both eyes was 6/12. Correction for Right eye was +1.00 cylindrical at 145 degree and for Left eye was +1.00 spherical. Near vision Unaided was N10 in both eyes and with an addition of +2.5 Ds became N6.

\section{Ocular examination}

Eyelids, Conjunctiva, Sclera and cornea were normal in both eyes. Anterior chamber was deep (Grade 4 by Van Herick method using Slit lamp). Pupils were of normal size and normal reaction. Both lens had immature senile cataract (Grade- Cortical -1 by LOCS [Lens Opacities Classification System] III). Intra Ocular Pressure [IOP] by Schiotz Tonometry was $17.3 \mathrm{~mm} \mathrm{Hg}$ in both eyes. Direct Ophthalmoscopy revealed Advanced POAG in both eyes. Visual field assessment using medmont perimeter showed severe glaucomatous field changes with right eye having only central ten degree visual field and left eye having lower arcuate field defect with advancing superior arcuate defect.

\section{Dashavidha pareeksha ( Tenfold Examination)}

His Prakriti was Vatakapha. Vikriti was Vata pradhana Tridosha with involvement of Prana and Vyana Vayu, Alochaka Pitta and Tarpaka Kapha. He was in Vridhavastha ( old age). His Satwa ( psyche), Sara ( excellence of tissues), Samhanana ( Compactness of organs), Ahara shakti ( power of food intake and digestion), Satmya ( suitability) and Pramana ( measurements of body organs) were of Madhyama ( moderate) level. His Vyayama shakti ( power of performing exercises) was avara (poor).

\section{Ashtavidha pareeksha ( Eightfold Examination)}

His Nadi ( pulse) was dhruta (fastly pulsating), Mutra (urine) was of prakrita varna (normal colour) Mala (stool) was rooksha and badha (Hard and constipated), Jihwa (tongue) had upalepa (coated), Shabda (voice) was spashta (clear), Sparsha (Touch) Anushna sheeta ( normal temperature), Akrithi (body built) was Madhyama ( moderate) and Drik (vision) was Heena (reduced).

\section{Sroto pareeksha ( Examination of body channels)}

Rasavaha, Raktavaha, Mamsavaha and medovaha srotas ( blood circulating and supporting channels of aqueous pathway and microvasculature of optic nerve) are involved and the pathology is Margavarodha and Vimarga gamana ( obstruction and flowing abnormal) possibly manifested as elevated IOP and optic nerve and retinal nerve fibre layer degeneration.

\section{Diagnostic assessment}

Laboratory investigations before treatment revealed $\mathrm{Hb}-13.1$ gms $\%$, FBS - 99mg/dl, Serum cholesterol$138 \mathrm{mg} / \mathrm{dl}$, Serum triglycerides-205mg/dl. Other hematological findings were within normal limits. Visual acuity for near and distant vision was done using Snellens near vision chart and Snellens distant vision box. Detailed assessment of anterior chamber of eyewas done with slit lamp biomicroscopy with anterior chamber angle depth assessed using Van Herick's method. IOP measurement was done with Schiotz Tonometer. Fundus photo was taken, which confirmed the diagnosis of Advanced POAG in both eyes [Figure - 1\&2]. Visual field analysis showed preserved central field in right eye and double arcuate defect in left eye [Figure $-3,4,5 \& 6$ ]. 
Figure 1\& 2 - Optic disc of Right and Left eye respectively

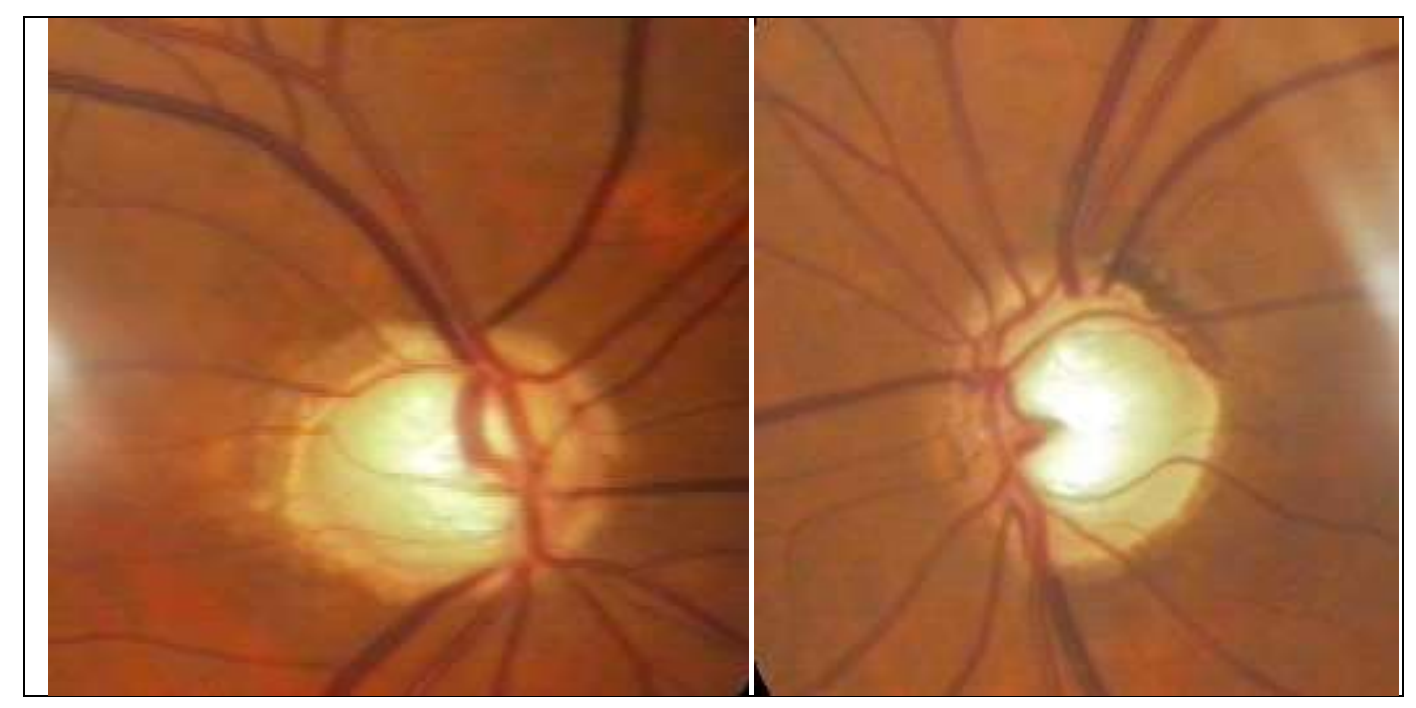

Figure 3 \& 4- Visual field of Right eye before and after treatment respectively

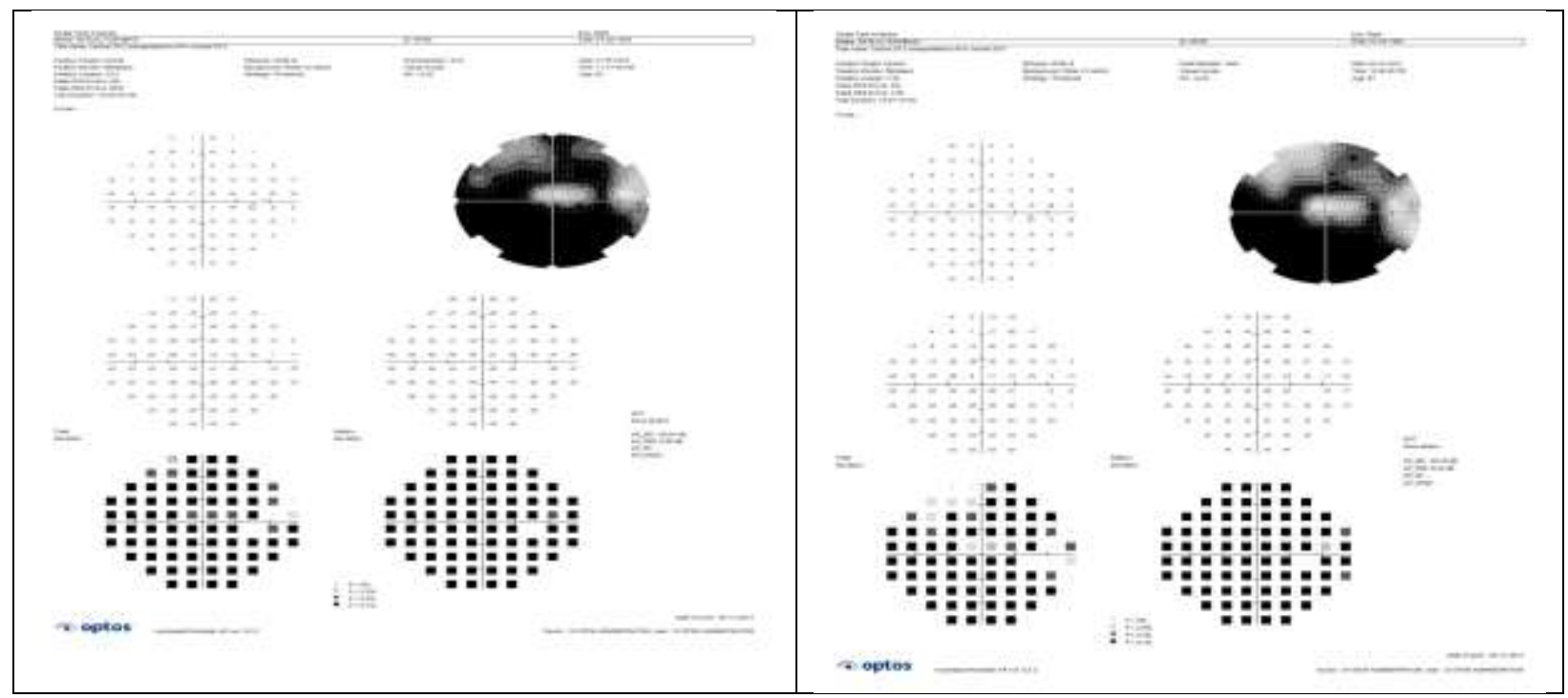

Figure 5 \& 6- Visual field of Left eye before and after treatment respectively

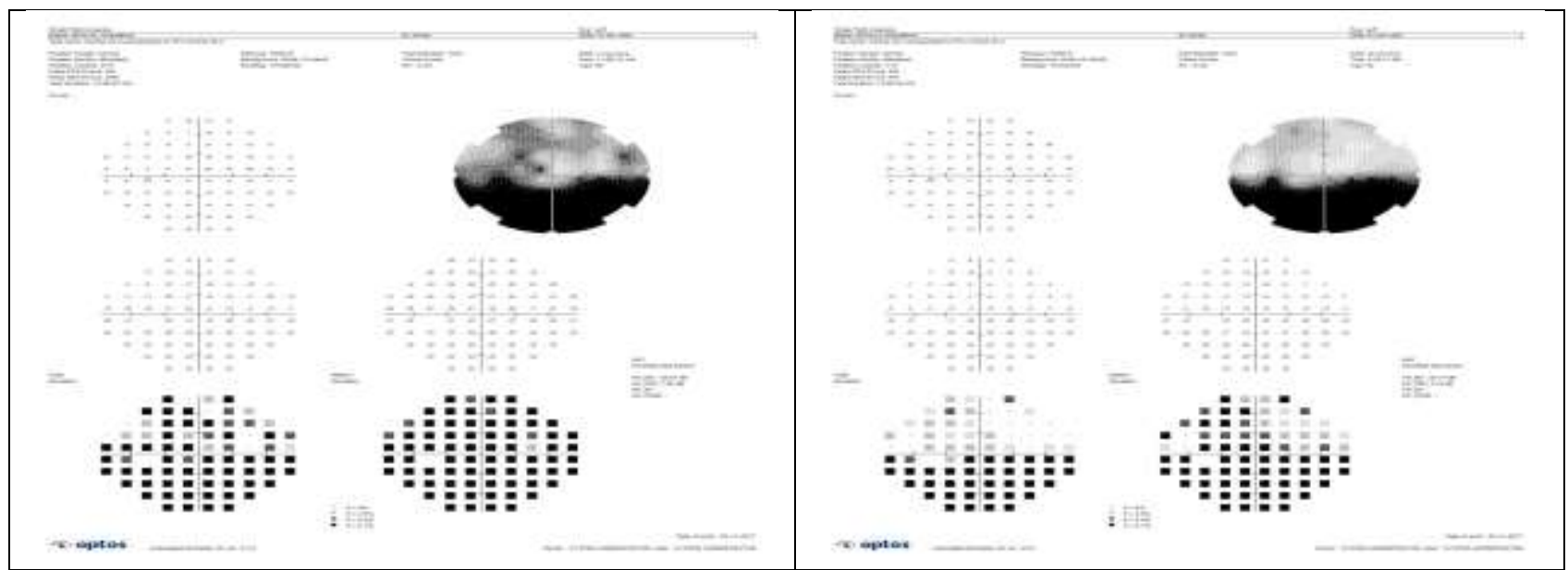


Archana V K ${ }^{1}$, International Journal of Ayurvedic\& Herbal Medicine 7(6) Nov.-Dec. 2017 (3024-3029)

Therapeutic intervention: The interventions are tabulated in Table-1.

\begin{tabular}{|c|c|c|c|c|}
\hline $\begin{array}{l}\text { Sl. } \\
\text { No. }\end{array}$ & Procedure & Medicine used & Duration & Posology \\
\hline 1 & $\begin{array}{l}\text { Deepana, pachana, } \\
\text { anulomana }\end{array}$ & $\begin{array}{l}\text { Erandabhrishta } \\
\text { Hareetaki }^{4}\end{array}$ & 5 days & $\begin{array}{l}6 \text { gms with hot water at } \\
\text { bed time. }\end{array}$ \\
\hline 2. & Marsha nasya & Anutaila $^{5}$ & Next 7 days & $\begin{array}{l}10 \text { drops instilled in each } \\
\text { nostril at morning. }\end{array}$ \\
\hline 3. & Tarpana & Shigru Arka ${ }^{6}$ & $\begin{array}{l}\text { After a gap of one week of } \\
\text { Nasya for seven days. }\end{array}$ & $\begin{array}{l}25 \mathrm{ml} \text { over eyes bounded } \\
\text { with a paste of black gram } \\
\text { powder for } 25 \text { minutes. }\end{array}$ \\
\hline 4. & Shamana yoga & Rasayana yoga & $\begin{array}{l}\text { Started after deepana, } \\
\text { pachana \& anulomana and } \\
\text { was continued for } 3 \text { months } \\
\text { along with other procedures. }\end{array}$ & $\begin{array}{l}2 \text { gms with half teaspoon } \\
\text { Madhu and one teaspoon } \\
\text { Ghrita at bed time. }\end{array}$ \\
\hline
\end{tabular}

Tarpana with Shigru Arka was done twice a month for 1 week with a gap of 1 week in between and continued for 3 months.

Table-2 Improvement in vision

\begin{tabular}{|l|l|l|l|l|}
\hline \multirow{2}{*}{} & Right Eye & After Treatment. & Before Treatment. & After Treatment. \\
\cline { 2 - 5 } & Before Treatment. & $6 / 12$ & $6 / 12 \mathrm{p}$ & $6 / 12$ \\
\hline DV & $6 / 18$ & $6 / 9$ & $6 / 12$ & $6 / 9$ \\
\hline BCVA & $6 / 12$ & $6 / 12$ & $6 / 12$ & $6 / 12$ \\
\hline PH & $6 / 18$ & N6 & N6 & N6 \\
\hline NV (BC) & N6 &
\end{tabular}

D.V- Distant Vision; B.C.V.A- Best Corrected Visual Acuity; P.H-Pin Hole Correction; N.V-Near Vision; BC- Best corrected.

Table -3 Reduction in Intraocular pressure

\begin{tabular}{|l|l|l|l|l|}
\hline & \multicolumn{2}{|l|}{ Right Eye } & Left Eye & After Treatment \\
\hline & Before Treatment & After Treatment & Before Treatment & $14.6 \mathrm{~mm} \mathrm{Hg}$ \\
\hline IOP & $17.3 \mathrm{~mm} \mathrm{Hg}$ & $17.3 \mathrm{~mm} \mathrm{Hg}$ & $14.6 \mathrm{~mm} \mathrm{Hg}$ & \\
\hline
\end{tabular}

IOP- Intraocular pressure

Table-4 Contents of Rasayana Yoga:

\begin{tabular}{|l|l|l|l|l|}
\hline Sr. No. & Drug & Scientific/ Botanical Name & Parts used & Quantity \\
\hline 1 & Suvarna Makshika & Chalcopyrite & Bhasma & $60 \mathrm{mg}$ \\
\hline 2 & Abhraka & Mica & Bhasma & $60 \mathrm{mg}$ \\
\hline 3 & SaptamrutaLauha & Lauha Formulation & Choorna & $250 \mathrm{mg}$ \\
\hline 4 & $\begin{array}{l}\text { Rasayanachurna } \\
\text { Guduchi } \\
\text { Gokshura } \\
\text { Amalaki }\end{array}$ & $\begin{array}{l}\text { Tinospora cordifolia Willd. } \\
\text { Tribulus terrestris Linn. } \\
\text { Emblica officinalis Gaertn. }\end{array}$ & & gm \\
\hline
\end{tabular}

\section{RESULTS:}

There was improvement in visual acuity and IOP in both eyes [Table 2]. Fundus examination findings were unchanged with no progression of cupping [Figure 4\&5]. The only significant blood parameter change was in Serum Triglyceride level from $205 \mathrm{mg} / \mathrm{dl}$ to $153 \mathrm{mg} / \mathrm{dl}$. Visual field analysis showed mild improvement in retinal sensitivity with no further progression of defects. Visual acuity and IOP was maintained during the follow-up period also. 


\section{DISCUSSION:}

The pathogenesis of POAG can be described at two level viz. at the level of aqueous outflow system and at the level of optic nerve head and retina. As per the mechanical theory, the supportive structure of optic nerve, lamina cribrosa gets compressed in POAG patients ${ }^{7}$ either due to raised IOP or inherent weakness of the tissue leading to distortion and damage to axons. This can also cause ischemia/ hypoxia by compressing the capillaries supplying these axons thus disrupting normal axoplasmic flow and cell death. Vascular theory suggests impaired auto regulation of Optic nerve vessels. The Ayurvedic interpretation of the mechanical and vascular mechanisms refers to Prana and Vyana Vayu dushti ${ }^{8}$.

Impaired autoregulation occurs due to Prana Vayu dushti resulting in vasospasm (Samkocha and Vikasaabnormal constriction and dilatation) and causes Vyana Vayu dushti (factor for fluid transport in body) and ischemia. This reduction in blood circulation and nutrients indicates srotavarodha at the level of rasayanis (obstruction in microchannels providing nourishment) and results in dhatu kshaya (tissue loss) ${ }^{9}$. The hypoxia at $\mathrm{ONH}$ indicates pranavaha srotodushti. As the circulation of rasa-rakta (the vehicle of nutritional factors for dhatus, the structural elements) is impaired rasavaha srotodushti leading to dhatu kshaya (degeneration) can be considered as a component of pathogenesis.

Srotorodha also occurs in aqueous outflow channels as a result of dhatwagni mandhya causing malasanchaya. Ama or malasamchaya means deposition of unwanted or waste materials in the body tissues which disturbs the homeostasis, ultimately leading to functional and structural damage. Normal outflow of aqueous depends upon the integrity of ouflow structures especially in the Trabecular meshwork (TM) and determines the IOP. In POAG, there is increased extracellular matrix (ECM) deposition (Malasanchaya) in TM and cellular components of ciliary body caused by decreased activity or Matrixmetalloproteinases (dhatwagnimandhya). This imparts resistance to the fluid passing through it (Srotorodha) causing Margavarodhajanya Vata kopa resulting in elevated IOP.

The signalling mechanisms of immune system initiated by high IOP, ischemia, and excessive excitatory amino acids can cause neuronal cell death ${ }^{10}$. Auto antibodies against Glycosaminoglycans which maintain the structural and functional at $\mathrm{ONH}$ were found in eyes of POAG patients. A lack of cell-mediated immunity has been observed as leukocyte migration inhibition is found in POAG patients. These all implies Vyadhikshamatwahani ${ }^{11}$ leading to progressive damage of optic nerve.

Thus majority of the risk factors and pathological mechanisms involved in pathogenesis of glaucoma indicate the role Vata dysfunction which regulates the activities of other two doshas viz. Pitta and Kapha. In the later stages of glaucoma all three doshas turn abnormal while Vata continue to play a predominant role. Agnimandya, malasamchya, margavarodha, pranavaha and rasavaha srotodushti and Vyadhikshamatwahani also seem to play a significant role in glaucomatous damage ${ }^{12}$. All these aspects should be kept in mind while selecting the therapeutic interventions.

Deepana, Pachana and Anulomana was done to relieve agnimandhya both at Koshta (gastrointestinal) and Dhatu (tissue) level and to bring Vata doshanulomana (homeostasis of Vata). Having Samagni is the base for being healthy and to have proper metabolism and absorption of the drug. Erandabhrishta Hareetaki was used for this purpose as can achieve all the above. Shiro virechana was done with Anu taila owing to its properties of Indriyasroto pravesa i.e. permeating into minute channels and margavishodhana (removes obstruction). ${ }^{[22]}$ Tarpana with Shigru Pallava Arka was selected since it is said to be Srotoshodhaka which helps to remove the Marga-Avarodha and Sanga \& also Chakshusya in nature. Arka is the most potent preparation with less chance of irritation and allergies. Rasayana yoga is an experience based herbo mineral powder [Table 3] being practiced at Institute for Post Graduate Teaching and Research in Ayurveda, Jamnagar, containing Chakshushya and Rasayana drugs. The ingredients were having immunomodulatory, adaptogenic, antioxidant and neuroprotective activities. Honey and ghee which also had Chakshushya properties was added to the combination for its targeted and synergistic action on ocular tissue. Overall effect of the therapy was removal of obstruction and improved nourishment of occular tissues which resulted in reduction of IOP, improved retinal sensitivity and vision.

Patient was using conventional anti-diabetic and anti-hypertensive drugs throughout these days of Ayurvedic management. No adverse events were reported during the study and follow-up period. This indirectly reveals that the conventional and traditional drugs concomitantly used in this case are not interacting with each other. 


\section{CONCLUSION:}

Thus, it can be concluded that Ayurvedic approaches are helpful in managing degenerative diseases like Primary open angle glaucoma. This study also emphasizes that Ayurveda can play a significant role in the integrated management of this condition. Considering such beneficial activities of Ayurveda approaches; there is a need to undertake collaborative researches to generate evidences at large scale.

\section{REFERENCES}

1. Brandt JD: Corneal thickness in glaucoma screening, diagnosis and management, Curr Opin Ophthalmol 15: 85, 2004.

2. Quigley H, Broman A: Number of people with glaucoma worldwide in 2010 and 2020, Br $\mathbf{J}$ Ophthalmol 90: 262, 2006.

3. https://www.researchgate.net/profile/Narayanam_Srikanth/publication/215556738_Select_Research leads_in_Ayurvedic_Ophthalmology/links/07f45cae4043cfba60ee3e53/Select-Research-leads-inAyurvedic-Ophthalmology.pdf?origin=publication_list

4. Sharma P V, Classical uses of medicinal plants, ist edition, Chaukhamba Sanskrit Sansthan, Varanasi, 1996.

5. Arunadatta, commentator, Ashtanga Hridaya, Sutra sthana, Nasyavidhi Adhyaya, 20/38, Reprint, Chaukhamba Sanskrit Sansthan, Varanasi, 2011,294

6. Dr. Indradev Tripathi, commentator, Hindi commentry, Arka Prakasha, Triteeya Shataka, 2nd edition, Chaukhambha Krishnadas Acedemy, Varanasi, 2006, 48.

7. Quigley HA, Hohman RM, Addicks EM et al::Morphologic changes in the lamina cribrosa correlated with neural loss in open-angle glaucoma, Am J Ophthalmol 95:673, 1983.

8. Dalhana, commentator, Sushruta Samhita, Sutrasthana, Doshadhatumalakshayavridhi vijnaneeyam Adhyaya,15/1, Reprint, Chaukhamba Sanskrit Sansthan, Varanasi,2014,69.

9. Agnivesha: commentator, Charaka Samhita, Vimanasthana, Chapter 5/25, Reprint, Chaukhamba Sanskrit Sansthan, Varanasi, 2011.

10. Mona Pache, and Josef Flammer: A Sick Eye in a Sick Body? Systemic Findings in Patients with Primary Open-angle Glaucoma. Survey of Ophthalmology Volume 51, 3 May-June 2006.

11. Dalhana, commentator, Sushruta Samhita, Sutrasthana, Doshadhatumalakshayavridhi vijnaneeyam Adhyaya,15/20, Reprint, Chaukhamba Sanskrit Sansthan, Varanasi,2014,71.

12. Kumar M, Varshney S, Maurya O. Pathogenesis of glaucoma: integration of biomedical and ayurvedic perspectives. Http://www.jreim-ayushjournal.com/?mno=191784 [access: december 11, 2017]. 